\title{
A Note on Recent Income Tax Developments Impacting Charitable Organisations in South Africa
}

\author{
Lee-Ann Steenkamp \\ Senior lecturer, Department of Accounting, University of the Western Cape \\ Email: lee-ann@outlook.com
}

Doi:10.5901/mjss.2014.v5n20p676

\begin{abstract}
The regulatory and fiscal environment in which South African charitable organisations operate have changed significantly over the past decade. This paper examines recent income tax developments which affect public benefit organisations (PBOs). A literature review was performed, with reference to statutory law, published articles and textbooks. The regulatory framework governing non-profit organisations (NPOs) is first considered. Thereafter, the income tax requirements relating to PBOs are addressed. Lastly, the paper reviews the rollover treatment for excess deductible donations, the deductible donations of appreciated immovable property and the interpretation of the expression 'substantially the whole'. The current and future income tax treatment of these aspects are examined. It was found that the section $18 \mathrm{~A}$ deduction was enhanced by allowing the excess amount (above the allowable threshold) to be carried over to future years of assessment. The incentive for deductible donations on 99-year endorsements for land conservation was improved. Greater clarity is now provided with regard to the requirement of 'substantially the whole'. It is submitted that these changes will assist in supporting charities in the vital role they play towards greater fiscal and social reform.
\end{abstract}

Keywords: charity, donation, non-profit organisation, public benefit organisation, tax deduction

\section{Introduction}

Internationally, charitable organisations are granted some degree of preferential tax treatment, including donor incentives, although the eligibility, criteria and available benefits vary from country to country. ${ }^{1}$ In South Africa, twenty years after the onset of a democratic political system, the challenge to promote greater economic and social equity continues: income and wealth inequality, unemployment and HIVIAIDS are rife. The South African government acknowledges the significant role that NPOs can play in society, stating that they 'undertake a shared responsibility for the social and development needs of the country thereby relieving the financial burden, which otherwise falls on the State' (SARS, 2007:3).

On 1 September 1998, the Non-Profit Organisations Act 71 of 1997, as amended (NPO Act), came into effect. According to the preamble to the Act, its aim is to provide for an environment in which non-profit organisations (NPOs) can flourish and to establish an administrative and regulatory framework within which NPOs can operate. ${ }^{2}$ In its most recently updated Basic Guide to Income Tax for Public Benefit Organisations, the South African Revenue Service (SARS) highlights the importance of this regulatory framework, stating (SARS, 2013:2) -

'Approved PBOs have the privilege and responsibility of spending public funds, which they derive from donations or grants, in the public interest on a tax-free basis. The donations or grants may be received from the general public or directly or indirectly from the State. It is therefore important to ensure that exempt organisations use their funds responsibly and solely for their stated objectives, without any personal gain being enjoyed by any person including the founders and the fiduciaries.'

In light of the regulatory and fiscal fields on which South African charitable organisations have to play, this paper has as its primary objective the analysis of recent income tax developments impacting these worthy entities. ${ }^{3} \mathrm{~A}$ literature review was performed, with reference to statutory law, published articles and textbooks. The research is structured as

\footnotetext{
${ }^{1}$ For an informative summary of the tax provisions pertaining to charitable giving in the United States, Australia, the Netherlands and Austria, see Heidenbauer, Hemels, Muehlmann, Stewart, Thömmes and Tukić (2013).

2 Section 2 of the NPO Act states the objects of the Act, which include, amongst others, the promotion of co-operation and shared responsibility within government, donors and other interested persons in their dealings with NPOs.

3 It is considered beyond the scope of this paper to examine other types of tax consequences, for example, that of Value-added Tax (VAT), although it is conceded that this could be a topic for future research.
} 
follows:

- The paper commences with a brief analysis of the regulatory framework within which NPOs must operate.

- The paper subsequently considers the income tax requirements relating to public benefit organisations (PBOs).

- Lastly, the paper examines, in greater depth, recent income tax revisions. These are: the rollover treatment for excess deductible donations, the deductible donations of appreciated immovable property and the interpretation of the expression 'substantially the whole'. For each of these concepts, the paper will firstly state the existing law and thereafter the amendments.

\section{Regulatory Environment}

The new Companies Act 71 of 2008, as amended (COA), and the Companies Regulations came into effect on 1 May 2011 and replaced the previous Companies Act 61 of 1973, in an attempt to modernise South Africa's legislation and to align it with international best practice. The COA provides for two main categories of entities, viz. profit and non-profit companies (NPC).

Essentially, a NPC is the successor to the 'association not for gain' and replaces 'companies limited by guarantee' and section 21 companies (Department of Trade and Industry, 2010:18). The basis for the establishment of the NPC would be its Memorandum of Incorporation which must set out at least one object of the company, and each such object must be either a public benefit object or an object relating to one or more cultural or social activities, or communal or group interests. ${ }^{4}$

It should be noted that incorporation as a NPC does not automatically result in income tax exemptions being granted by the Commissioner of SARS in terms of the Income Tax Act No 58 of 1962, as amended (the ITA). ${ }^{5}$ The tax status is granted in terms of compliance with the requirements of section 30 of the ITA. Accordingly, the next section of this paper will briefly consider the tax environment relating to PBOs. ${ }^{6}$

\section{Tax Environment}

\subsection{Background}

Following recommendations by the Katz Commission, the Minister of Finance announced wide-ranging changes to the legislation regulating the income tax exemption of NPOs in his 2000 National Budget Speech. ${ }^{7}$ The objective of the new legislation was to cluster certain types of entities together and treat them uniformly and provide more certainty for taxpayers and the Commissioner on the qualifying requirements of tax exempt entities (SARS, 2007:3).

The Taxation Laws Amendment Act No 30 of 2000, which came into operation on 15 July 2001, introduced two new concepts, viz. a 'public benefit organisation' and a 'public benefit activity.' As required by the ITA, the Minister has approved a list of qualifying public benefit activities which may be expanded from time to time by notice in the Government Gazette. The new provisions are more detailed and comprehensive than was previously the case, resulting in more consistency and greater certainty. Specific sanction measures have also been introduced to deal with situations where a PBO misuses its exempt status or does not comply with the provisions of the ITA. The legislative requirements relevant to the focus of this paper, will be concisely dealt with in the next paragraph.

\footnotetext{
${ }^{4}$ In terms of item 1(1) of Schedule 1 of the COA. Note that all of the provisions of the COA apply to NPCs, subject to the provisions, limitations, alterations or extensions set out in section 10 and in Schedule 1.

${ }^{5}$ A PBO is defined in section 30(1) of the ITA and refers, amongst others, to a NPC as defined in section 1 of the COA, or a trust or an association of persons that has been incorporated, formed or established in South Africa. The reference to section 1 of the COA is in effect from 1 January 2011. Furthermore, foreign companies, associations or trusts can also qualify, provided that they are exempt from tax in that overseas country.

${ }^{6}$ For an analysis of the interplay of the COA and the ITA with regard to the concepts of NPCs and PBOs (for example, fiduciary responsibility and the distribution of funds), see Steenkamp (2011).

7 The Katz Commission was appointed by the Minister of Finance on 22 June 1994. It was mandated to compile a number of reports dealing with tax reform in South Africa. The Ninth Report dealt with fiscal issues affecting NPOs and was released during 1999 (National Treasury, 1999).
} 


\subsection{Legislative requirements}

A PBO is defined in section 30 of the ITA. Generally, such an entity must have as its sole or principal object the carrying on (in a non-profit manner and with a philanthropic intent) of one or more public benefit activities. These activities, which are set out in the Ninth Schedule to the ITA, must be for the benefit of the general public at large and comprise the following -

- Welfare and humanitarian;

- Health care;

- Land and housing (for retired persons, clinics etc.);

- Education and development;

- Religion, belief or philosophy;

- Cultural;

- Conservation, environment and animal welfare;

- Research and consumer rights;

- Sport (non-professional);

- Providing of funds, assets or other resources to other PBOs;

- Support services to other PBOs; and

- Hosting certain international events.

If the PBO meets the requirements of section 30 (which includes obtaining approval by the Commissioner of SARS), it can qualify for tax exempt status under section $10(1)(c \mathrm{~N})$. In terms of section 10(1)(cN), the receipts and accruals of an approved PBO are exempt from normal tax, to the extent that these amounts are not derived from any business undertaking or trading activity. ${ }^{8}$ Consequently, it could also qualify to issue section $18 \mathrm{~A}$ tax deduction certificates to its donors. The following relief from income tax applies in respect of transactions with an approved PBO (Haupt, 2014:792): ${ }^{9}$

- Income tax relief on non-trade income and on part of the trading income of the PBO;

- the PBO need not register for provisional tax; and

- the section $18 \mathrm{~A}$ deduction for donations made to certain PBOs.

The balance of the receipts and accruals from trading activities will be taxed at 28 per cent - irrespective of whether the PBO operates as a trust or a NPO (Kamdar, 2013:19). The next section will elaborate on the section 18A deduction and will examine recent amendments to the ITA which pertain to the income tax relief stated above. These legislative developments were identified by Steenkamp (2014). ${ }^{10}$

\footnotetext{
${ }^{8}$ Stighlingh, Koekemoer, van Schalkwyk, Wilcocks and de Swardt (2014:130) summarise the exemption granted by section 10(1)(cN) by distinguishing between receipts and accruals derived -Otherwise than from any business undertaking or trading activity or; From any business undertaking or trading activity, if the undertaking or activity is integral and directly related to the sole or principal object of the organisation (the basis on which the activity is carried out must substantially be directed at the recovery of costs and may not result in unfair competition in relation to taxable entities), the undertaking or activity is of an occasional nature and undertaken substantially with assistance on a voluntary basis without compensation, orthe undertaking or activity is approved by the Minister by notice in the Government Gazette; or From any business undertaking or trading activity other than the above, the receipts and accruals will be exempt from normal tax to the extent that it does not exceed the greater of five per cent of the total receipts and accruals of the organisation during the relevant year of assessment and R200 000.

${ }^{9}$ Although beyond the scope of this paper, it is perhaps pertinent to mention the other types of tax relief available to PBOs (Haupt 2014:792); however, these will not be elaborated on - No donations tax on donations to PBOs;No estate duty on bequests to PBOs;No capital gains tax on assets disposed of to PBOs (as well as on certain assets disposed of by PBOs);Zero-rating VAT on supplies made by certain PBOs;VAT exempt supplies of donated goods; No transfer duty on purchase of fixed property in certain cases;

No securities transfer tax on certain transfers of shares; and Associations not for gain can elect to account for VAT on a payment basis.

10 Written permission to use the published article's sources and research findings in this paper was obtained from the editor of that journal to ensure that no copyright rules were contravened.
} 


\title{
4. Recent Income Tax Developments
}

\subsection{Rollover treatment for excess deductible donations}

\subsubsection{Current treatment}

Section 18A allows for a deduction in respect of a bona fide donation (in cash or in kind) made by a taxpayer to certain approved PBOs. ${ }^{11}$ It should be cautioned that not all tax-exempt PBOs can issue tax deduction certificates to donors. Moreover, section $18(2 \mathrm{~A})$ requires that the donation be utilised solely in carrying on activities contemplated in Part II of the Ninth Schedule. In order to qualify for a deduction, the donation has to be actually paid or transferred during the year of assessment.

Currently, the deductible portion may not exceed ten per cent of the taxable income of the taxpayer before the deduction in terms of section $18 \mathrm{~A}$ and the medical deduction of section 18 (the latter deduction only applies to individuals). As section $18 \mathrm{~A}(1)$ refers to the 'taxable income' of the taxpayer, it stands to reason that a taxpayer with no taxable income or an assessed loss will be unable to claim the deduction. Lastly, any excess donation (i.e. the amount exceeding the ten per cent deduction) is permanently lost and cannot be utilised to further reduce future taxable income. Fortunately, this rule has been relaxed by a recent legislative amendment.

\subsubsection{Amendment}

The 2013 Taxation Laws Amendment Act 31 of 2013 (TLAA), introduced a much welcomed relief by allowing the above excess donation to be rolled over as a deductible donation in the subsequent year of assessment (again subject to the ten per cent rule). ${ }^{12}$ If any excess remains, the excess can be further rolled over again. The amendment applies to donations paid or transferred during years of assessment commencing on or after 1 March 2014. This respite is contained in an added proviso to section 18A(1)(B) which reads as follows:

\begin{abstract}
'Provided that any amount of a donation made as contemplated in this subsection and which has been disallowed solely by reason of the fact that it exceeds the amount of the deduction allowable in respect of the year of assessment shall be carried forward and shall, for the purposes of this section, be deemed to be a donation actually paid or transferred in the next succeeding year of assessment.'
\end{abstract}

The Explanatory Memorandum on the Taxation Laws Amendment Bill, 2013 (Explanatory Memorandum) explains [at paragraph 1.3] that while Government remains committed to the ten per cent limitation, there is concern that the ceiling has an 'unduly harsh impact' on large donations. In attempt to address this concern, taxpayers can now arrange their affairs so as to spread large donations over multiple years.

Table 1 below illustrates the amendment from the perspective of a R150 000 donation made by an individual taxpayer to an approved PBO. This adjusted example is derived from the Explanatory Memorandum (National Treasury 2013:par1.3) and Steenkamp (2014:29).

Table 1: Calculation of amended section 18A deduction - adjusted rollover

\begin{tabular}{|l|c|l|c|}
\hline \multicolumn{2}{|c|}{ Year of assessment ending 28 February 2015 } & \multicolumn{2}{c|}{ Year of assessment ending 28 February 2016 } \\
\hline Taxable income & R1 000000 & Taxable income & R1 500 000 \\
\hline Actual donations made & R150 000 & Actual donations made & Rnil \\
\hline Allowable donation as a deduction (10\% of R1 million) & R100 000 & Allowable donation as a deduction (10\% of R1.5 million) & R150 000 \\
\hline Section 18A deduction & R100 000 & Section 18A deduction (limited to amount rolled over) & R50 000 \\
\hline Amount rolled over & R50 000 & Amount rolled over & Rnil \\
\hline
\end{tabular}

\footnotetext{
11 De Koker and Williams (2014:par8.40) question the requirement that the donation be bona fide. Their argument is that since the word 'donation' is not defined and so must be given its ordinary meaning, this interpretation requires the words 'bona fide' to be tautological or even nugatory and so might be deficient.

12 The ten per cent limit is based on taxable income excluding any retirement fund lump sum benefit, retirement fund lump sum withdrawal benefit and now also severance benefits (the latter was inserted by the TLAA).
} 


\subsection{Deductible donations of appreciated immovable property}

\subsubsection{Current treatment}

A donation may be made in the form of cash or property (the latter is also sometimes referred to as 'in kind'); both these types are generally subject to the annual ten per cent ceiling as discussed in the paragraph above. Section $18 \mathrm{~A}(3)$ deals with the valuation of donations in kind and determines the amount to be deducted as follows -

- Trading stock donated: amount equals cost price; or

- Other property: lower of cost to the donor (less any allowances claimed) or the fair market value on the date of donation.

The Explanatory Memorandum [at paragraph 2.5] provides two reasons for the 'lower of cost or market value' rule. Firstly, taxpayers should not obtain a deduction for pre-tax amounts (this is a reference to untaxed gains) and secondly, government was concerned that taxpayers overvalued their property so as to artificially enhance the deduction.

A concomitant incentive is the section $37 \mathrm{C}$ deduction of the cost of environmental conservation and maintenance on land. The allowance is available if this work is done in terms of a biodiversity management agreement that has a duration of five years and the agreement has been entered into by the taxpayer in terms of the National Environmental Management: Biodiversity Management Act 10 of 2004. Until 2008, the income tax system has failed to recognise landowners for incurring nature conservation maintenance expenses for the public good and for loss of a right to the use of the land. Consequently, section 37 was introduced with effect 1 January 2009 to address this imbalance. ${ }^{13}$

If the land is declared to be a national park or nature reserve with an endorsement on the title deed for at least 99 years, the lower of the cost or the market value of the land is treated as a section $18 \mathrm{~A}$ deductible donation. However, unlike regular deductible donations, the value of the deduction is spread over ten years at ten per cent per annum. Unsurprisingly, in a study regarding the uptake of tax incentives for biodiversity conservation in the Western Cape of South Africa, the research findings indicate that landowners seemed to prefer the use of fiscal and economic incentives, such as subsidies and the supply of materials (Van Wyk, 2010:73). However, only a relatively small portion (about one third) of landowners indicated that tax incentives would encourage them to commit more land for conservation (Van Wyk, 2010:73). To that end, any legislative adjustments that offer greater tax relief are to be welcomed. The next paragraph addresses one such amendment.

\subsubsection{Amendment}

In order to enhance the incentive for deductible donations on 99-year endorsements for land conservation, the TLAA provides that donations of appreciated immovable property that qualify as capital assets will be allowed to exceed cost. The Explanatory Memorandum recognises [at paragraph 2.5] that in some instances (for example, if the land has been passed on through family generations) the fair market value of the land is considerably larger than the cost. Therefore, failure to account for this appreciation basically negates most of the potential tax benefit for making a donation or a 99year private endorsement.

Consequently, in terms of the amended rule, the deductible amount above cost will equal the lower of market or municipal value. The Explanatory Memorandum notes [at paragraph 2.5] that the municipal value limit will prevent the existence of excessive deductions caused by artificial valuations. ${ }^{14}$ The value of the section $18 \mathrm{~A}$ donation is calculated by using a newly introduced formula, inserted in section $18 \mathrm{~A}(3 \mathrm{~A})$ :

$A=B+(C \times D)$, where

- $A=$ the amount of the deductible donation

- $\mathrm{B}=$ the cost of the land and buildings

- $\quad \mathrm{C}=$ the notional capital gain that would have arisen if the land had been sold at the lower of market value or

\footnotetext{
${ }^{13}$ Stiglingh et al (2014:300) differentiate between the various deductions available in terms of section 37 - Biodiversity agreements: noncapital land conservation and maintenance expenditure will be treated as being incurred in the production of income and for trade purposes and are therefore deductible under the general deduction formula of section 11(a);Protected area agreements: land conservation and maintenance expenses are treated as a deemed deductible donation for the purposes of section 18A; and Land declared a national park or nature reserve: the land qualifies for the section $18 \mathrm{~A}$ deduction, based on the calculation discussed in the paragraph below.

14 The use of the municipal value of land was recommended in Van Wyk's study (2010:72), as it would lead to a somewhat larger tax benefit and ensure an objective and consistent measurement of all the land under investigation.
} 
municipal value on the day of the donation

- $\mathrm{D}=$ capital gains tax inclusion rate (66.6 per cent for individuals or special trusts and 33.3 per cent in any other case)

The amendments are applicable to donations paid or transferred during years of assessment commencing on or after 1 March 2014. The amount $(\mathrm{A})$ is treated as a section $18 \mathrm{~A}$ donation spread over ten years. However, in terms of the revised rollover rule, the non-deductible portion will be carried forward to the next year of assessment.

Table 2 below illustrates the amendment from the perspective of a 99-year endorsement of farm land by an individual who owns the farm. The farmland has a base cost of R250 000. The donation is made during the year of assessment ending 28 February 2015. This adjusted example is derived from the Explanatory Memorandum (National Treasury, 2013:par2.5) and Steenkamp (2014:30).

Table 2: Calculation of amended section 18A deduction -appreciated immovable property

\begin{tabular}{|l|c|}
\hline Taxable income & R1 000000 \\
\hline Municipal value of farm land & R3 000 000 \\
\hline Market value of farm land & R3 400 000 \\
\hline B & R250 000 \\
\hline C $=$ R3 000 000 - R250 000 & R2 750 000 \\
\hline D & $66.6 \%$ \\
\hline A = B + (C x D) = R250 000 + (R2 750 000 x 66.6\%) & R2 081 500 \\
\hline Allowable donation as a deduction (10\% of R1 million) & R100 000 \\
\hline S 18A deduction & R100 000 \\
\hline Amount rolled over = R2 081 500 - R100 000 & R1 981 500 \\
\hline
\end{tabular}

\subsection{Interpretation of the expression 'substantially the whole'}

\subsubsection{Current treatment}

Under the partial taxation system a PBO is allowed to conduct a business undertaking or trading activity within certain prescribed parameters. Receipts and accruals derived from those activities in excess of prescribed limits are taxable (although the PBO retains its overall tax exemption status).

This exemption is contained in section $10(1)(C N)(i i)(a a)(B)$ which determines that the business undertaking or trading activity -

'is carried out or conducted on a basis substantially the whole of which is directed towards the recovery of cost'.

\subsubsection{Development}

SARS issued Binding General Ruling No. 20 on 10 December 2013 to provide clarity on the interpretation of the expression 'substantially the whole'. ${ }^{15}$ In terms of the ruling, 'substantially the whole' is regarded by SARS to mean 90 per cent or more. However, in order to overcome certain practical difficulties SARS will accept a percentage of not less than 85 per cent. The ruling acknowledges that the percentage must be determined using a method appropriate to the circumstances.

The following potential practical difficulties could be encountered (Lamprecht, 2014):

- It is currently unclear what SARS regards as 'practical difficulties'.

- Although the practice generally prevailing had been to use a percentage of 85 per cent, organisations could have been exempt from tax on business activities if 83 per cent or 84 per cent of the income from these activities were directed towards the recovery of cost. However, the new percentage could take organisations unawares.

- Consequently, PBOs could lose their tax exemption on business undertakings or trade activities.

${ }^{15}$ This expression is referred to in sections 10(1)(cN), 10(1)(cO), 30B, paragraph 63A of the Eighth Schedule to the ITA and section 9(1)(c) of the Transfer Duty Act. 


\section{Conclusion}

While government continues to be the primary mechanism through which structural change can be effected, civil society and philanthropy have a role to play in addressing poverty eradication and development (Kuljian, 2005:4). Indeed, charitable organisations have a valuable contribution to make to society and they fill an important lacuna in the ability of the government to address all the social and development needs of the country (Pretorius, 2012:21).

The efficient management of NPOs throughout South Africa - and ultimately Africa - is central to the future development of the continent (Rippon \& Moodley, 2012:92). It is therefore promising that the South African government recognises the vital role that a tax system can play in supporting the work done by charities. After all, as SARS (2007:3) states -

'Tax benefits are designed to assist non-profit organisations by augmenting their financial resources and providing them with an enabling environment in which to achieve their objectives.'

This paper has reviewed recent legislative income tax amendments impacting charitable organisations. It was found that the section 18A deduction was enhanced by allowing the excess amount (above the allowable threshold) to be carried over to future years of assessment. The incentive for deductible donations on 99-year endorsements for land conservation was improved. Greater clarity is now provided with regard to the requirement of 'substantially the whole'. It is submitted that these changes will assist in supporting charities and are a welcome step towards greater fiscal and social reform as previously envisaged more than a decade ago by the Katz Commission.

\section{References}

Department of Trade and Industry. (2010). The Companies Act, No 71 of 2008, An Explanatory Guide. Pretoria: Government Printer. De Koker, A.P. and Williams, R.C. (2014). Silke on South African Income Tax. Durban: LexisNexis.

Haupt, P. (2014). Notes on South African Income Tax 2014. Roggebaai: Hedron.

Heidenbauer, S., Hemels, S., Muehlmann, B.W., Stewart, M., Thömmes, O. and Tukić, T. (2013). Cross-border charitable giving and its tax limitations. Bulletin for International Taxation, 67(11). Amsterdam: IBFD, 611-625.

Kamdar, M. (2013). Getting to grips with income tax and NGOs: tax professional. Tax Professional, (Quarter 3), 18-19.

Kuljian, C. L. (2005). Philanthropy and equity: The case of South Africa. Global Equity Initiative: Harvard University.

Lamprecht, I. (2014). Taxation of public benefit organisations changed. Moneyweb. [Online]. Available: http://www.moneyweb.co.za/ moneyweb-tax/taxation-of-public-benefit-organisations-changed (2 February 2014).

National Treasury. (1999). Ninth Interim Report of the Commission of Inquiry into certain Aspects of the Tax Structure of South Africa: Fiscal Issues affecting Non-Profit Organisations. Katz Commission of Inquiry. [Online]. Available: http://www.treasury.gov.za/ publications/other/katz/9.pdf (19 May 2014).

National Treasury. (2013). Explanatory Memorandum on the Taxation Laws Amendment Bill 2013. [Online]. Available: http://www.sars.gov.za/AllDocs/LegalDoclib/ExplMemo/LAPD-LPrep-EM-2013-02\%20-\%20Explanatory\%20Memorandum\%20 Taxation\%20Laws\%20Amendment\%20Bill\%202013.pdf (21 May 2014).

Pretorius, H. (2012). The tax treatment of public benefit organizations. TAXtalk, 34, 20-23.

Rippon, A. and Moodley, I. (2012). Not for profit, not necessarily, not for gain: African perspectives on social entrepreneurship: research. Journal of Management \& Administration, 10(2), 82-106.

South Africa. (2000). Non-Profit Organisations Act No. 71 of 1997. Pretoria: Government Printer.

South Africa. (2000). Taxation Laws Amendment Act No. 30 of 2000. Pretoria: Government Printer.

South Africa. (2004). National Environmental Management: Biodiversity Management Act No. 10 of 2004. Pretoria: Government Printer.

South Africa. (2008). Companies Act No. 71 of 2008. Pretoria: Government Printer.

South Africa. (2013). Taxation Laws Amendment Act No. 31 of 2013. Pretoria: Government Printer.

South Africa. (2014). The Income Tax Act No. 58 of 1962. Pretoria: Government Printer.

South African Revenue Service (SARS). (2007). Tax exemption guide for Public Benefit Organisations in South Africa. [Online]. Available: http://www.sars.gov.za/AllDocs/OpsDocs/Guides/LAPD-Gen-G03\%20-\%20Tax\%20Exemption\%20Guide\% 20 for\%20 Public\%20Benefit\%20Organisations\%20in\%20South\%20Africa\%20-\%20External\%20Guide.pdf (9 May 2014).

South African Revenue Service (SARS). (2013). Basic Guide to Income Tax for Public Benefit Organisations. [Online]. Available: http://www.sars.gov.za/AllDocs/OpsDocs/Guides/LAPD-IT-G16\%20-\%20Basic\%20Guide\%20to\%20Income\%20Tax\%20for\%20 Public\%20Benefit\%200rganisations\%20-\%20External\%20Guide.pdf (26 April 2014).

Steenkamp, L-A. (2011). The relationship between non-profit companies and public benefit organisations. TAXtalk, 30, 14-16.

Steenkamp, L-A. (2014). Public benefit organisations and tax: where is the charity and justice?: features. TAXtalk, 45, $27-31$.

Stighlingh, M., Koekemoer, A.D., van Schalkwyk, L., Wilcocks, J.S. and de Swardt, R.D. (2014). Silke: South African Income Tax. Durban: LexisNexis.

Van Wyk, E. (2010). Tax incentives for biodiversity conservation in the Western Cape. Meditari Accountancy Research, 18(1), 58-75. 